\title{
Antibiotics Classification and Visual Target Sites for Bacterial Inhibition
}

\author{
Firoz Khan* \\ Department of Pharmaceutical Technology, Meerut Institute of Engineering and \\ Technology, India
}

*Corresponding author: Firoz Khan, M. Pharm (Pharmacology), Department of Pharmaceutical Technology, Meerut Institute of Engineering and Technology (MIET), Delhi, India, Tel: +91-9012537941; Email: fkpharmacy@gmail.com

\section{Mini Review \\ Volume 3 Issue 3}

Received Date: August 20, 2018

Published Date: September 06, 2018

\begin{abstract}
We know that cell is the structural and functional unit of the entire microorganism. Some bacterial cell is also composed of cell wall and genetic material to do. If the microorganism invade in the human body it will became a disease state for the human. So, we did finds some target site of bacteria for killing or inhibit these invading bacteria's. Some of the antibiotics are specific to act on cell wall such as Penicillin's and Cephalosporin's other are also available for inhibit the growth of gram negative or gram negative bacteria' (Sulfamethoxazole, Quinolones etc). In this review the classification or target site action of the particular antibiotic are described for the accurate use of antibiotics to inhibit the growth of foreign particle in the human body.
\end{abstract}

Keywords: Antibiotics; Target sites; Cell wall

\section{Introduction}

The term antibiotic was coined from the word "antibiosis" which literally means "against life". In the past, antibiotics were considered to be organic compounds produced by one microorganism which are toxic to other microorganisms [1]. With related to this, these (Antibiotics) are the substances that can be produced or developed by the microorganism, which selectively inhibit the generation of or kill the microorganism (that are harmful for human heath) at very low concentrations [2].

While some antibiotics are able to completely kill other bacteria, some are only able to inhibit their growth. Those that kill bacteria are termed bactericidal while those that inhibit bacterial growth are termed bacteriostatic [3]. Mostly all of the antibiotics have effect through inhibition of cell wall synthesis, leakage from cell wall, inhibit protein synthesis, destruction of bacterial DNA and metabolism related to bacteria. All of the action of the antibiotics have depend upon the cell wall or cell parts of the bacteria where the antibiotics work and target the specific cell to inhibit or kill. So, cell is very specific target for about all of the antibiotics [4].

\section{Classification of Antibiotics}

Antibiotics or antimicrobial drugs are classified on many of ways i.e. they based on their chemical as well as based upon their mechanism of action. 


\section{Advances in Pharmacology and Clinical Trials}

\begin{tabular}{|l|l|}
\hline Penicillins & $\begin{array}{l}\text { 1. Natural:- Penicillin G, Penicillin-VK 2. Penicillinase Resistant: - Methicillin, Nafcillin, } \\
\text { Oxacillin and other. 3. Aminopenicillins:- Ampicillin }\end{array}$ \\
\hline Fluoroquinolones & $\begin{array}{l}\text { First generation:- Norfloxacin, Ofloxacin, Ciprofloxacin, Pefloxacin. Second generation:- } \\
\text { Levofloxacin, Moxifloxacin, Lomefloxacin, Gemifloxacin, Sparfloxacin, Prulifloxacin. }\end{array}$ \\
\hline Aminogycosides & Streptomycin, Gentamycin, Kanamycin, Tobramycin, Amikacin, Sisomicin, Netilmicin. \\
\hline Monobactams & Aztreonam \\
\hline Carbapenems & Imipenem, Meropenem, Faropenem, Doripenem \\
\hline Macrolides & Azithromycin, Clarithromycin, Dirithromycin, Erythromycin, Clindamycin, Roxythromycin. \\
\hline Others & $\begin{array}{l}\text { Clindamycin, Vancomycin, Linezolid, Rifamycin, Tetracyclin, } \\
\text { Trmethoprim/Sulfamethoxazole, Chloramphenicol and others [5]. }\end{array}$ \\
\hline
\end{tabular}

Table 1: Classification of antibiotics based on structure.

\begin{tabular}{|l|l|}
\hline \multicolumn{2}{|c|}{ Antibiotic Grouping By Mechanism } \\
\hline Cell Wall Synthesis & $\begin{array}{l}\text { Penicillins, Cephalosporins,Vancomycin, Beta-lactamase inhibitors, Carbapenems, } \\
\text { Aztreonam, Polymycin, Bacitracin }\end{array}$ \\
\hline $\begin{array}{l}\text { Protein Synthesis } \\
\text { Inhibitors }\end{array}$ & $\begin{array}{l}\text { Inhibit 30s Subunit:- Aminoglycosides (gentamicin). } \\
\text { Inhibit 50s Subunit:- Macrolides, Chloramphenicol, } \\
\text { Clindamycin, Linezolid, Streptogramins. }\end{array}$ \\
\hline DNA Synthesis Inhibitors & Fluoroquinolones, Metronidazole \\
\hline RNA synthesis Inhibitors & Rifampin \\
\hline $\begin{array}{l}\text { Mycolic Acid synthesis } \\
\text { inhibitors }\end{array}$ & Isoniazid \\
\hline $\begin{array}{l}\text { Folic Acid synthesis } \\
\text { inhibitors }\end{array}$ & Sulfonamides, Trimethoprim [6] \\
\hline
\end{tabular}

Table 2: Classification of antibiotics based on mechanism of action.

\section{Antibiotics Target Site or Mode of Action}

To know the target site of a specific antibiotic firstly know about the structure of the antibiotic and where it can be attached. Most of the antibiotic target through the cell of bacteria and destroy it either inhibit the growth by entering in the cell material or inhibit the formation of genetic material. The target sites of the antibiotics are as follows:

- Inhibition of cell wall synthesis

- Breakdown of cell membrane structure or function

- Inhibition of the structure and function of nucleic acids

- Inhibition of protein synthesis

- Blockage of key metabolic pathways

Sometimes it is not easy to describe the target site of the antibiotic action. It can be proposed by using some visual images to describe the clear attachments of drug to its target site. Here the picture described the target site of antibiotics.

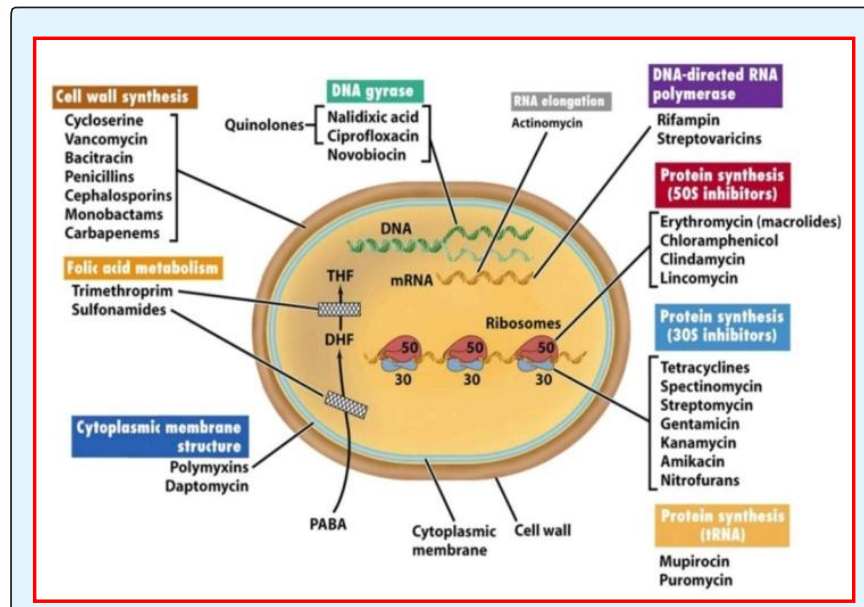

Figure 1: Antibiotics and their target site on the bacterial cell. 


\section{Advances in Pharmacology and Clinical Trials}

\section{Discussion}

The antibiotics shows high efficacy and low toxicity with low concentrations have the best antibiotic says by researcher or antibiotic guidelines. Many antibiotic are depend upon their spectrum of activity such as- Narrow or broad spectrum but the aim is to inhibit the growth of microorganism in the human body. All of us have different target sites but some of the antibiotic inhibit the bacterial growth by stepwise which belongs to bacterial cell material.

\section{Conclusion}

Antibiotics and their target site is specific to inhibit the growth of micorganism. Besides that nowdays the anibiotic resistance are spread day by day. So we need to find some more target area to target the bacterial cell which not be resist.

\section{References}

1. Patel U, Yan YP, Hobbs FW, Kaczmarczyk J, Slee AM, et al. (2001) Oxazolidinones mechanism of action:
Inhibition of the first peptide bond formation. J Biol Chem 276(40): 37199-37205.

2. Holten KB, Onusko E M (2000) Appropriate prescribing of oral beta-lactam antibiotics. Am Fam Physician 62(3): 611-620.

3. Kahne D, Leimkuhler C, Lu W, Walsh C (2005) Glycopeptide and lipoglycopeptide antibiotics. Chem Rev 105(2): 425-448.

4. Kang HK, Park Y (2015) Glycopeptide antibiotics: Structure and mechanism of action. J Bacteriol Virol 45(2): 67-78.

5. Lafontaine DL, Tollervey D (2001) The function and synthesis of ribosomes. Nat Rev Mol Cell Biol 2(7): 514-520.

6. Moore PB (2001) The ribosome at atomic resolution. Biochemistry 40: 3243-3250.

7. Fuoco D (2012) Classification framework and chemical biology of tetracycline-structure-based drugs. Antibiotics 1: 1-13.

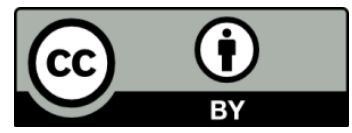

